\title{
Guaraná (Paullinia cupana) as a Commercial Crop in Brazilian Amazonia ${ }^{1}$
}

\author{
H. T. Erickson, ${ }^{2}$ Maria Pinheiro F. Corrêa, ${ }^{3}$ \\ AND JOSÉ RICARDO ESCOBAR ${ }^{3}$
}

\begin{abstract}
Guarana (Paullinia cupana) is a woody vine or sprawling shrub native to the central Amazon Basin. The seeds are commercially produced on some 6,000 ha in the state of Amazonas near Manaus. The principal article of commerce is an amber-colored, carbonated soft drink. It is also widely used as a high caffeine stimulant and in local medicines. The plant is monoecious and is damaged by a number of diseases, the most severe being anthracnose. Prospects are excellent for greatly expanded international markets.
\end{abstract}

Guaraná is the name of a carbonated nonalcoholic beverage marketed throughout Brazil, where it easily qualifies as the national soft drink. It is also the name of the source plant. Guaraná has reputed curative properties as well and is sold as an elixir and a medicant. It is widely touted as being able to restore properties of youth.

Commercial production of guaraná is virtually confined to the middle Amazon region of northern Brazil, between the Madeira and Tapajós rivers (Fig. 1). The city and county (municipio) of Maués are the focal point of the industry, accounting for $80 \%$ of the nation's (and world's) total supply as recently as 1980 . The past few years have seen some expansion in Amazonas (Table 1). About 6,000 ha are now under cultivation.

Guaraná is being sold in increasing amounts in Europe, North America and the Orient. Conceivably the day is approaching when it will become a familiar product in much of the industrialized world. Indeed, the soft drink usually finds ready acceptance among the newly initiated, as the amber liquid has a refreshingly mild, fruity flavor.

\section{BOTANY}

Guaraná, Paullinia cupana Kunth ex H.B.K., is in the Sapindaceae. The cultivated form is often referred to as Paullinia cupana variety sorbilis Ducke. Several species of Paullinia are found in the Amazon Basin and much remains to be resolved concerning the taxonomy of the genus.

In the primeval Amazonian forest $P$. cupana is a liana, its woody stems, supported by towering tree trunks, reach high into the forest canopy. Under cultivation, however, it becomes a sprawling shrub growing perhaps $2 \mathrm{~m}$ tall with a diameter twice as great (Fig. 2).

Leaves are pinnately compound, with 5 glabrous, shiny leaflets. The plant is evergreen. Its long, arching stems have deep longitudinal furrows, which are most pronounced in the new growth. Some have tendrils, which bear inflorescences,

\footnotetext{
${ }^{1}$ Received 7 September 1983; accepted 24 February 1984.

${ }^{2}$ Horticulture Department, Purdue University, West Lafayette, IN 47907.

${ }^{3}$ Empresa Brasileira de Pesquisa Agropecuaria, Manaus, Brazil.
} 


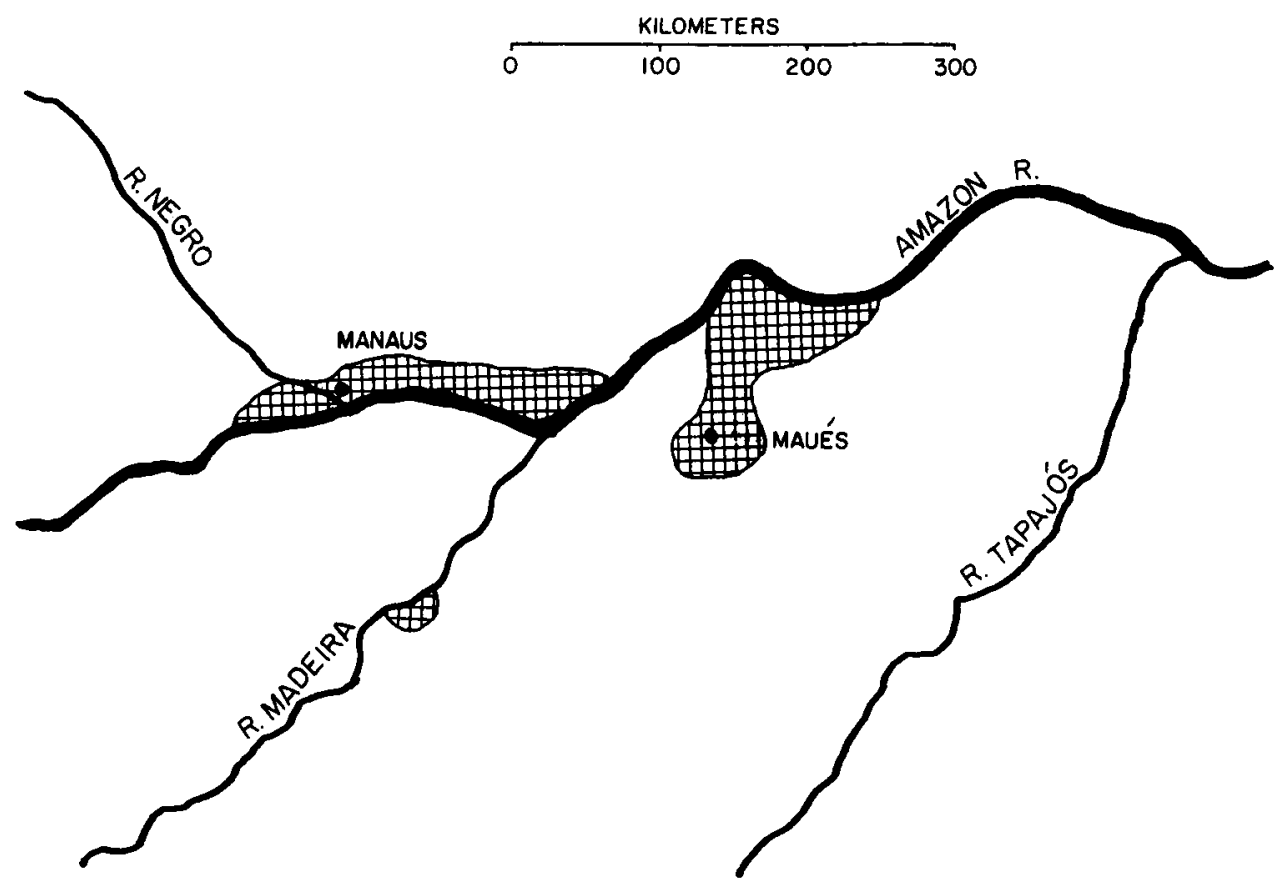

Fig. 1. Guaraná-producing regions of Amazonas, Brazil, with greatest concentration around Maués.

although most of the latter arise at nodes (Fig. 3). Trunks are characteristically bifurcate, branching near the soil surface. This trait in the heavily canopied plant leads to frequent trunk splitting, which in turn creates production and survival problems (Fig. 4).

Guaraná grows in the deep acidic oxisols of the Amazonian upland "terra firme" forest, near the equator. This hot, humid region has a pronounced dry season from June to September. Ten-year temperature and rainfall averages for Manaus are shown in Table 2 . While climatic conditions vary somewhat in different production areas, the Manaus data are generally representative. Low rainfall periods are associated with the flowering of numerous woody plants of the tropics, including guaraná. As the rains subside in May and June, inflorescences begin to expand noticeably, signaling the arrival of the flowering season.

Floral biology is one of the more intriguing features of this interesting species. Inflorescences are borne on new wood. Growth initiated early in the rainy season is already semihard when flowers begin to develop. Considerable new branch growth also occurs at the time of floral development and these branches are soft and succulent during flowering. Each inflorescence may be composed of several hundred buds clustered in small groups on racemes up to $30 \mathrm{~cm}$ long. The individual small, off-white flowers are unisexual although inflorescences include both staminate and pistilate flowers. This brings up one of the most engaging features of the plant. All open flowers on a given inflorescence, and all inflorescences on a flowering branch, will be of the same sex on any given day (Fig. 5). Meanwhile other branches of that plant may have simultaneous anthesis of the opposite sex. An inflorescence will have successive waves of flower production, 


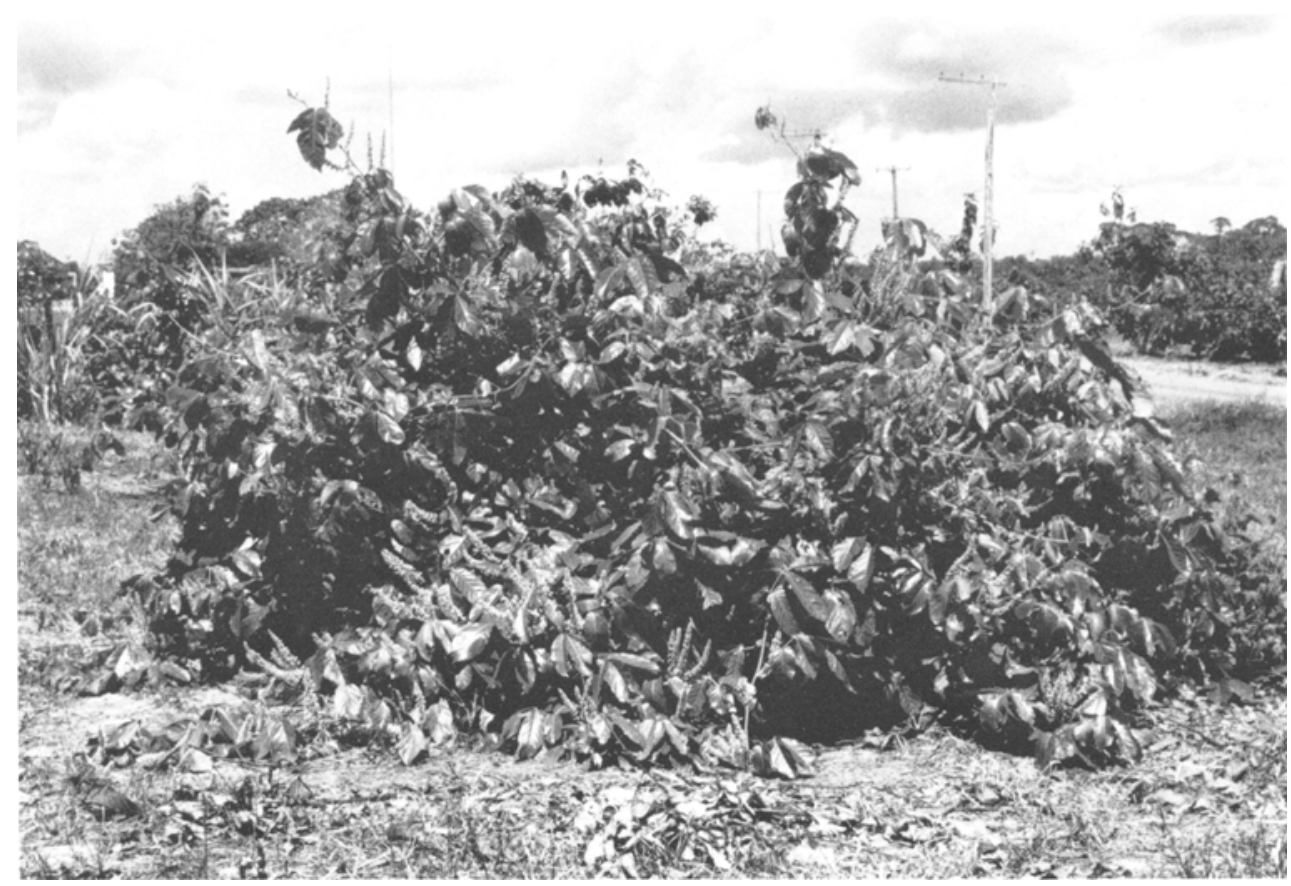

Fig. 2. A mature guaraná plant in full flower.

which can extend over a month or more. Each wave will be exclusively pistillate or staminate. Pistillate flowers are in the minority, about one sixth of the total (Schultz and Valois, 1974). They contain rudimentary anthers that fail to develop.

Onset of flowering varies from year to year and appears to depend on rainfall patterns. If rains persist and the dry season is tardy, flowering might be delayed until September. Customarily, substantial flowering occurs in July, peaking in August or early September. In 1983 the opposite occurred. Rains failed to arrive at their normal time and numerous plants began blooming in March, which is decidedly off-season. Fruit ripening would occur in the driest period of the year threatening substantial crop loss. We are not aware of conclusive data concerning the mode of action of rain on flower inhibition, whether it is due to the direct action of rainfall on inflorescence or shoot, or to soil moisture content.

Flowers open in early morning. Most pollen has disappeared by midday. Pis-

TABle 1. GuARANÁ PRODUCTION IN BRAZIL FOR 5 RECENT YeARS."

\begin{tabular}{|c|c|c|c|}
\hline \multirow[b]{2}{*}{ Year } & \multirow{2}{*}{$\begin{array}{c}\text { Area } \\
\text { ha }\end{array}$} & \multicolumn{2}{|c|}{ Production (metric tons dried seed) } \\
\hline & & Total & Yield/ha \\
\hline 1975 & 2,350 & 180 & 0.077 \\
\hline 1976 & 2,900 & 290 & 0.100 \\
\hline 1977 & 3,300 & 400 & 0.121 \\
\hline 1980 & 3,932 & 650 & 0.165 \\
\hline 1981 & 4,000 & 700 & 0.175 \\
\hline
\end{tabular}

\footnotetext{
a Annuário Estatistico do Brasil. Fundação Instituto Brasileiro de Geografia e Estatística.
} 


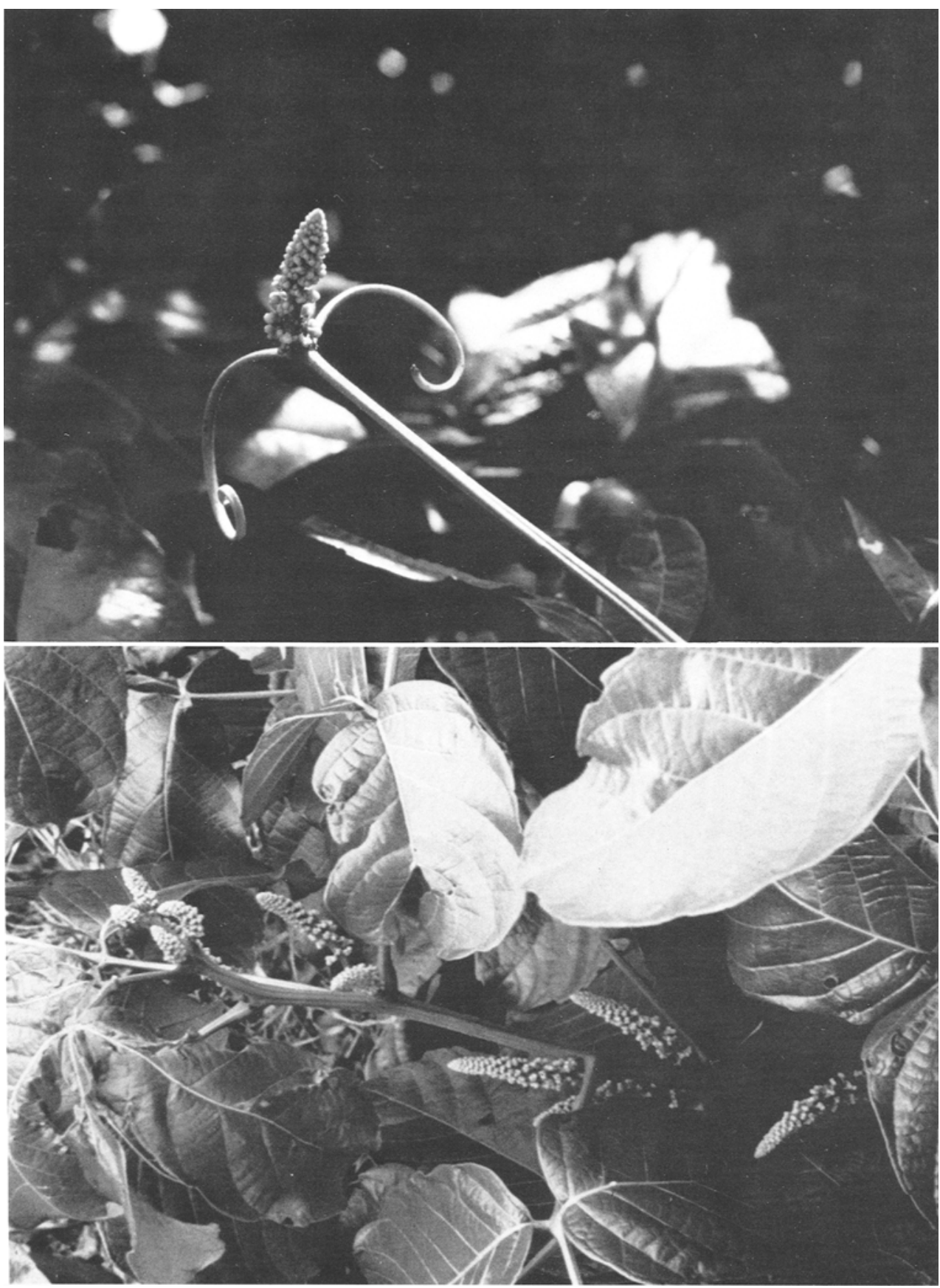

Fig. 3. Developing inflorescences on a typical fruiting branch (below) and an inflorescence arising from a tendril. 


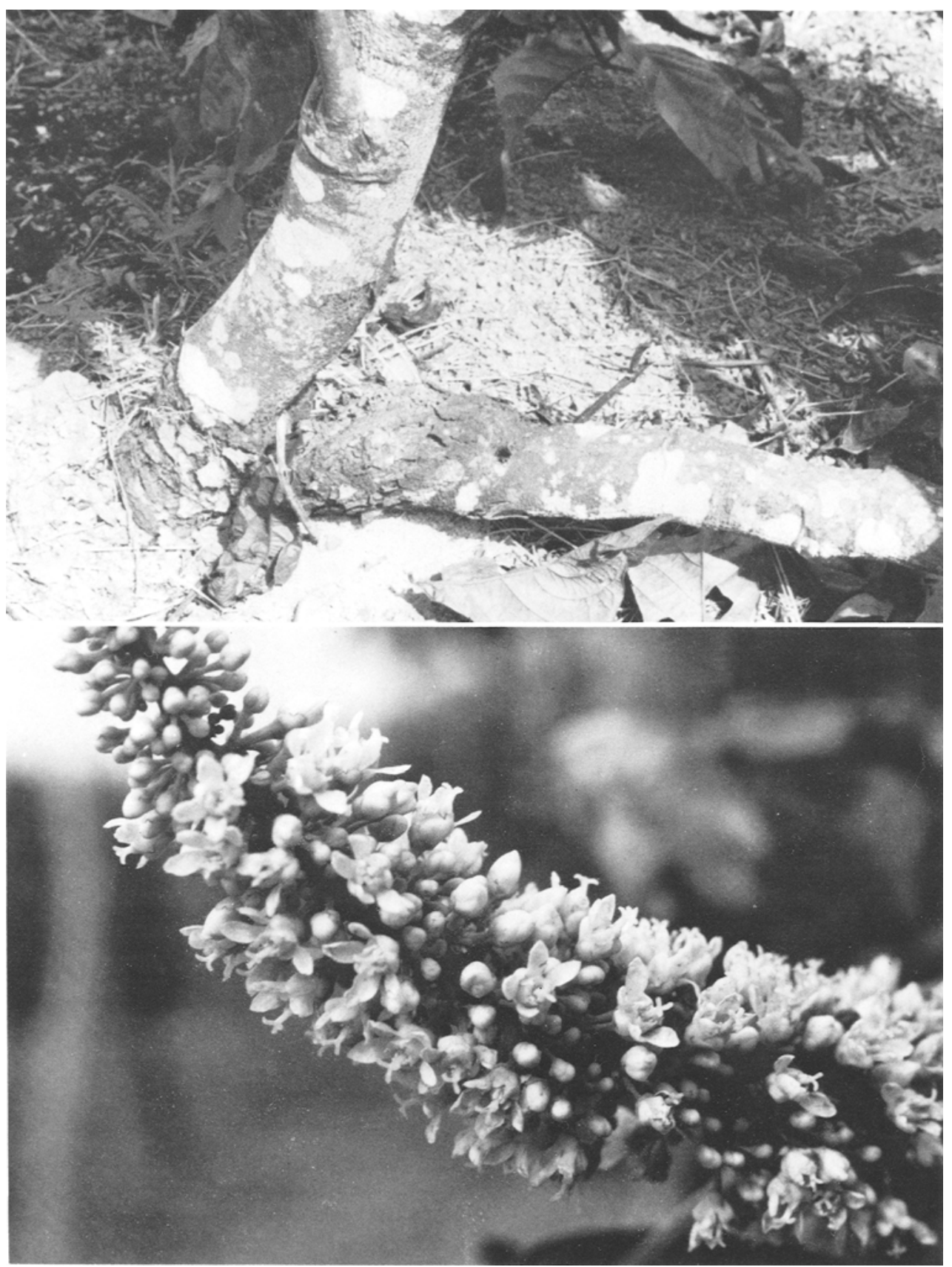

Fig. 4-5. Fig. 4 (above). Divided trunk of a guaraná plant that split at ground level. Fig. 5 (below). Pistillate flowers. All open flowers on an inflorescence are of the same sex $(\times 3 / 4)$. 

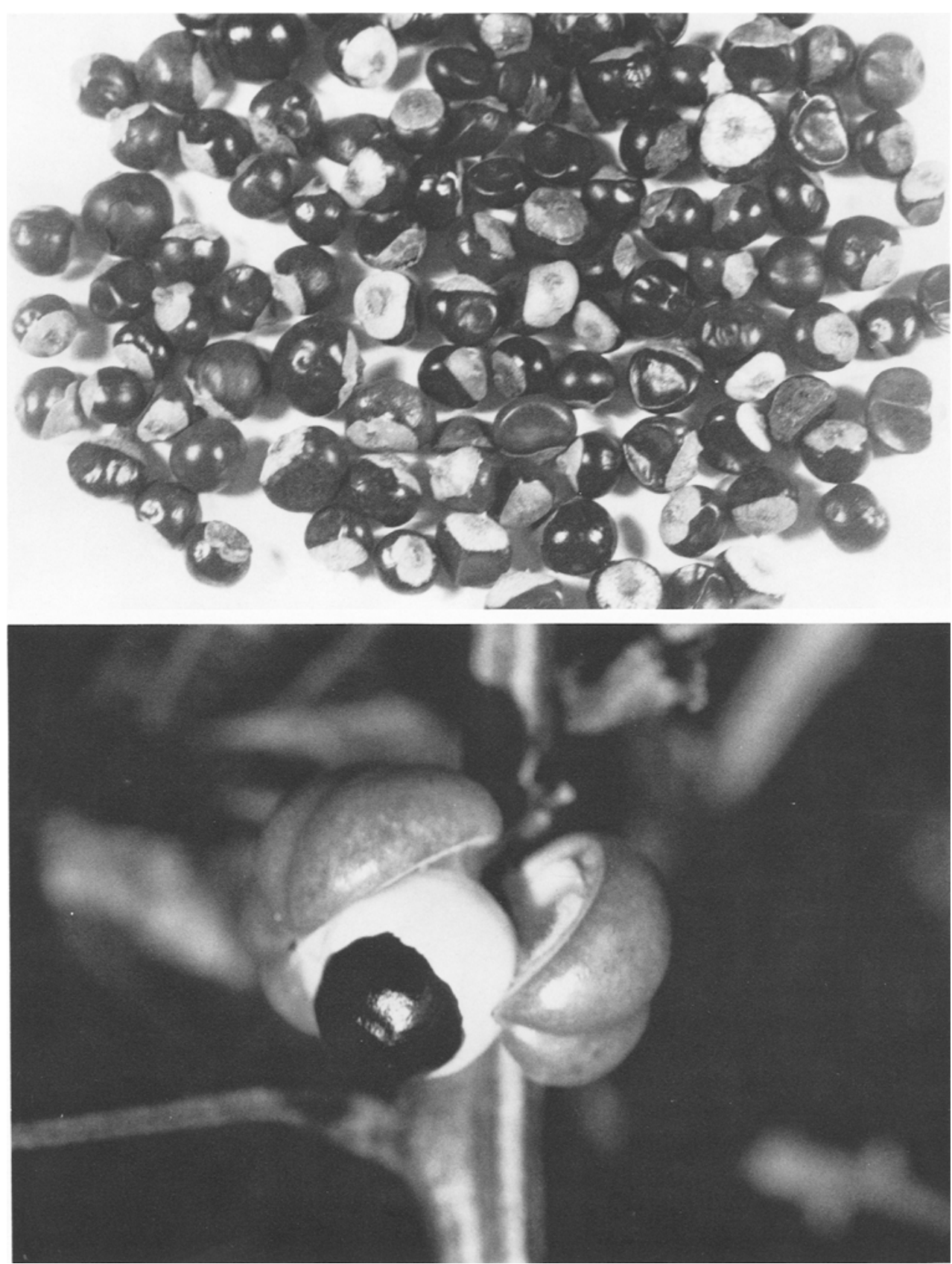

Fig. 6. Mature seeds (above) are similar to small buckeye nuts $\left(x^{3 / 4}\right)$. Newly dehisced fruit (below) with a single seed bedded in white aril material, resembles a human eye $(\times 1.5)$.

tillate flowers seem to be receptive for one day only. Pollination is by insects, primarily bees and wasps. Ants are numerous on all plants, with large numbers continually moving about the branches and leaves. Some pollen might be distributed by them as well. 

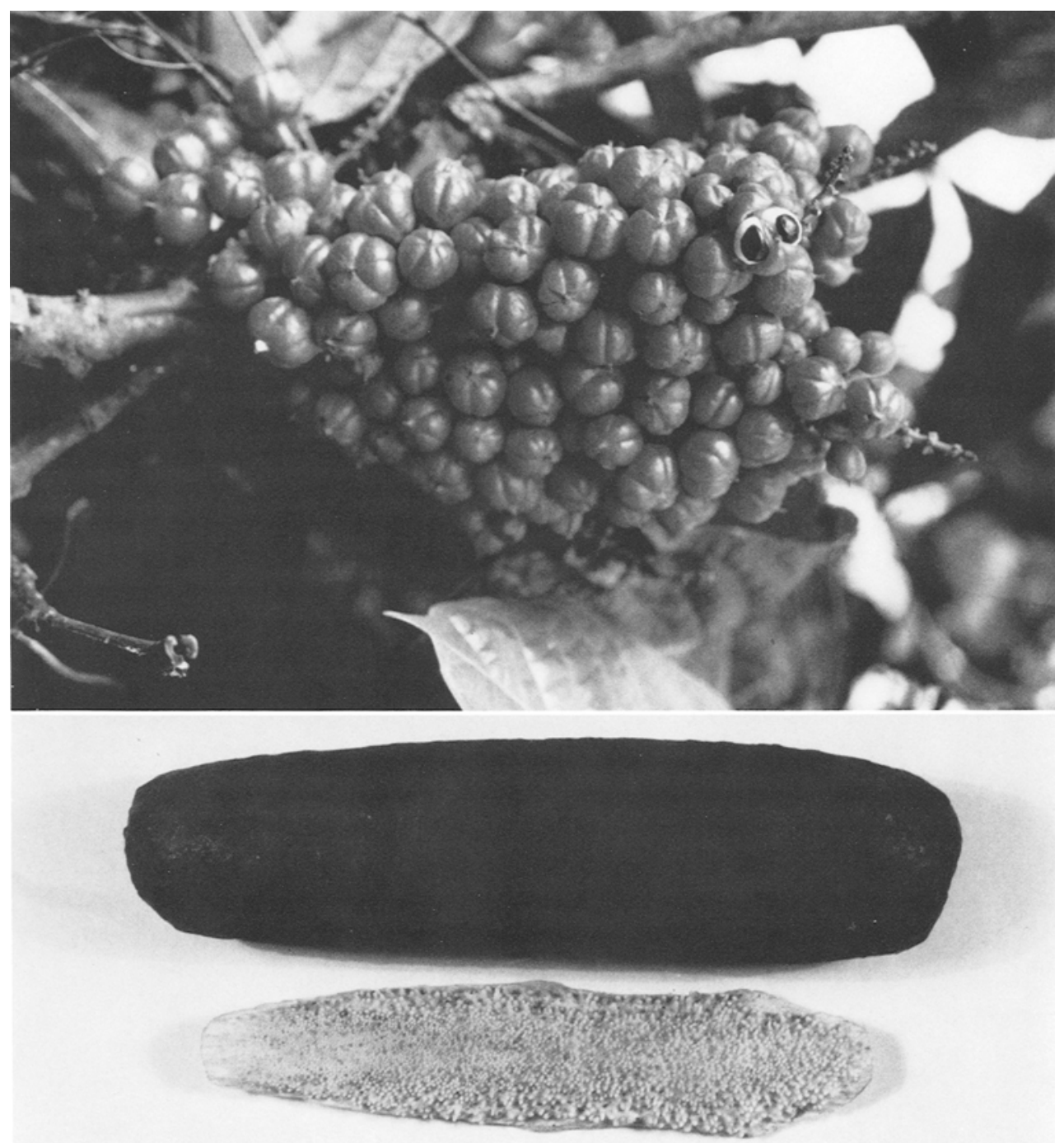

Fig. 7-8. Fig. 7 (above). A productive cluster of nearly mature fruit. Fig. 8 (below). A loaf (bastäo) of processed guaraná (upper) and the tongue of a pirarucú fish used as a rasp to pulverize small amounts as needed to prepare drinks $(\times 3 / 4)$.

The 3-loculate deep yellow to reddish-orange fruits ripen in about 75 days. They contain 1-3 dark brown seeds, $1 \mathrm{~g}$ or less dry weight, resembling small buckeyes (Aesculus). The fruit is a leathery capsule that dehisces at maturity. Immature seeds remain green virtually until the day of dehiscence, when they turn brown, and ready for harvest. The lower half of the seed is enclosed in a waxy, snow white aril that is exposed when the fruit opens. The dark brown seed against this white background bears a striking resemblance to the human eye, an impression fortified by the similarity in size (Fig. 6). This feature is largely responsible for the mysticism that guaraná possessed for the aborigines of the region. 
Table 2. Monthly temperature and rainfall data for Manaus, Amazonas, Brazil (10-YR AVERAGE, 1971-1981). ${ }^{\mathrm{a}}$

\begin{tabular}{lcccc}
\hline \hline \multirow{2}{*}{ Month } & \multirow{2}{*}{$\begin{array}{c}\text { Rainfall } \\
\mathrm{mm}\end{array}$} & \multicolumn{2}{c}{ Temperature $\left(^{\circ} \mathrm{C}\right)$} & \\
\cline { 2 - 4 } January & 248 & Av maximum & Av minimum & Av \\
February & 275 & 30.7 & 22.2 & 25.1 \\
March & 298 & 30.4 & 22.2 & 25.2 \\
April & 288 & 30.8 & 22.3 & 25.3 \\
May & 267 & 31.0 & 22.4 & 25.3 \\
June & 159 & 31.0 & 22.2 & 25.4 \\
July & 137 & 30.8 & 21.6 & 25.2 \\
August & 106 & 31.1 & 21.1 & 25.3 \\
September & 102 & 32.7 & 21.3 & 25.8 \\
October & 171 & 33.0 & 21.9 & 26.2 \\
November & 160 & 32.9 & 22.3 & 26.4 \\
December & 228 & 32.7 & 22.6 & 26.3 \\
Year & 2,439 & 31.9 & 22.3 & 25.8 \\
\hline
\end{tabular}

"Bol. Agrometeorol., 1981. EMBRAPA UEPAE/Manaus.

A single inflorescence often bears several dozen fruits in different stages of maturity because of the protracted flowering habit (Fig. 7). Seeds are composed of 2 fleshy cotyledons surrounded by a thin, woody coat. The embryo is immature at the time of fruit ripening. Germination is hypogeous and requires 1-3 mo. Seeds lose viability rapidly if permitted to dry out. Young plants have unifoliate leaves. After about the 6th to 10th leaf the mature compound leaves appear. Under prevailing growing conditions, new leaves on seedlings emerge at the rate of approximately one per month. The juvenile stage persists about $1 \mathrm{yr}$. Some plants flower when $1 \frac{1 / 2}{2}$ yr old, but 3-4 yr are required for commercially significant production.

\section{FOLKLORE}

Guaraná has a prominent place in the folklore of mid-Amazonian tribes, especially the Mundurucus. The strikingly eye-like appearance of the ripe fruit encouraged superstition, and this was reinforced by its potent stimulatory properties, as the seed is rich in caffeine.

Following is an account of the most quoted Indian legend explaining the origin of guaraná. A son born to a couple of the Maué tribe, so the story goes, was an exceptional child who spread happiness and good will wherever he went, a veritable angel. A jealous evil spirit resolved to eliminate the youngster. Despite close supervision by the tribe the child slipped out alone one day to collect fruit in the forest. The evil spirit, Iurupari, transformed himself into a snake that attacked and killed the child. When rescuers found him he was lying facing the sky, bearing a benevolent expression in death, eyes opened wide.

Soon thereafter a shattering bolt of lightening shook the earth, halting the lamentations of the assembled tribe. Enter the mother who gave a lengthy discourse on how she had received divine instructions to bury the excised eyes of the child. No one wanted to accept the gruesome task so a lottery was conducted, and the interment performed by the loser. Later a shrubby plant sprouted from the buried eyes. This was the first guaraná and its origin accounts for ripe fruit having the appearance of living eyes (Monteiro, 1965). 
Modifications of the story are told, all on the same general theme. What is clear is that guaraná figured prominently in aboriginal rituals and culture long before the arrival of Europeans. Caucasians are said to have become acquainted with guaraná products by 1775 , and probably much earlier, although we are not aware of a more precise date. Alexander von Humbolt (1822) and Alfred R. Wallace (1853) encountered guaraná on their 19th century travels in the Amazon. Both mentioned the therapeutic properties of the beverage, Wallace referring to it as "a preparation from a fruit, grated in water, to form an agreeable and medicinal drink." Benefits are said to include among others the cure of certain fevers, alleviation of heart problems, treatment of diarrhea and headache, and reduction of heat stress.

\section{PRODUCT}

Guaraná is marketed as a carbonated drink, a powder, a concentrate, as a hardened "loaf," in medicinal formulations, and even as handicraft art objects. Caffeine is a prominent component of the seeds, as much as $3.5 \%$ of fresh weight. Seed coats, which account for about $30 \%$ by weight, contain up to $3 \%$ caffeine. Theobromine is also present (Maravalhas, 1965).

Processing begins shortly after harvest. Seeds are first cleansed of the white arillate material in a water trough, a task usually performed by women and children. Seed must be dried to $10 \%$ moisture if stored for any time, to prevent spoilage. They are roasted in clay ovens, for 2-3 hr. Small amounts of water are thrown over the roasting seeds from time to time. As water evaporates, the seeds expand. They are then allowed to cool and re-harden before crushing. Milling requires some skill and experience. A kilo of seed is mixed with a can of water, the usual measure being a small condensed milk can. Seeds are pounded or beaten into tiny fragments, creating a product with a doughy texture.

The next step is to form the dough into small, hard loaves, called bastões. Two kilos of dough are removed and equally divided into portions of $125 \mathrm{~g}$ each. These are molded into cylinders about $15 \mathrm{~cm}$ in length and $3-4 \mathrm{~cm}$ wide. In the small factories each bastâo is stamped with an identifying number of the worker involved. Next they are dried and briefly exposed to a hot fire. Finally they are placed in a smoke house and left to harden for up to 40 days. Murici (Byrsonima crassifolia (L.) H.B.K.) wood is often used because of its desirable aroma when burned. The finished product is dark brown and best described as resembling a small, hard salami.

Consumers use this loaf by pulverizing portions as needed, the powder being added to water to form an instant beverage. Among aborigines this was done by using the ossified tongue of a pirarucú (Arapaima gigas Cuvier) fish as a rasp. This huge species is widespread in the Amazon River system, where it is prized for food and consumed either fresh or dried. Its bony tongue with hundreds of tiny "teeth" suggested the family name, Osteoglossidae. Pirarucú tongue is still utilized for this purpose and is commonly sold in shops throughout the region (Fig. 8). In recent years both the tongue and guaraná bastões have become familiar items in the tourist trade.

Some small farmers do their own processing. A family's production of 30 kilos per year of finished product is considered a good average. In addition to the pure 
product, cassava (Manihot esculenta Crantz), cacao (Theobroma cacao L.), or even quinine (Cinchona L. spp.) bark are added at times. Another product, guarana flor, a flour extracted from burned flowers is reported to be used.

Most consumers know guaraná only as a tasty carbonated beverage, usually served cold and available in numerous brands. The Antarctica $\mathrm{Co}$. was the first to offer it commercially, in 1909. Artificial flavoring is said to be in use although a national law requires a minimum of $60 \mathrm{mg}$ of natural product per liter. The biggest external markets are being developed in Japan where guaraná has recently become a familiar product in vending machines in Tokyo, and in the United States. About 28 tons of guaraná seed or its equivalent were exported in 1982 and this nearly doubled in 1983.

In 1982, 630 metric tons of an estimated national yield of 900 tons were used for soft drinks. Production was expected to fall to 500 tons in 1983 , because of unfavorable weather conditions. This would result in a serious product shortfall. Insufficient production presents a definite constraint to any vigorous market expansion program. Chronic shortages have encouraged the establishment of experimental plantations in other Brazilian states, some as far away as Bahia and São Paulo. The crop is, however, widely regarded as an Amazonian resource that should properly be developed in that region.

The "purists" prepare their own beverage from unadulterated guaraná powder or liquid concentrate. While its true medicinal properties may remain clouded by superstition and folklore, there is no doubt of its stimulatory properties. This can be ascribed to the $4 \%$ plus caffeine content of the dry solids. It is not uncommon for inhabitants of Amazonia to prepare routinely a glass for breakfast, much as a morning cup of coffee. They claim, with some justification, that this gives a physical and psychological lift for the entire day. To achieve this effect a daily intake of 1-2 $\mathrm{g}$ of natural product is recommended. Recent unfavorable publicity given caffeine may act as a damper on this type of consumption.

Mention was made of guaraná art objects. There is a small cottage industry of artisans who make jewelry such as pins and brooches and other artifacts from guaraná paste, formed and hardened as described for loaves. These dark terra cotta-like objects are marketed in their natural color or they may be tinted, depending on the style of the creator. An elderly man in Maués lamented the fact that no young people were being trained to do this work and he claimed to be the last artisan in the region. It might be a dying art form if his fears are valid.

\section{CULTURE}

This plantation crop is typically grown on land newly cleared of virgin forest. Plants are nursery grown from seeds that have been stratified in moist sawdust. Germination is erratic, taking place over a 1-3 mo period. As seedlings emerge they are planted in soil-filled, 1-liter containers made of black plastic film (Fig. 9). They are kept under heavy shade for nearly a year before field planting, in January and February, at the height of the rainy season. This permits plants to become established before moisture stress sets in. Plants are arranged in a square design; $4 \mathrm{~m} \times 4 \mathrm{~m}$ (625 plants/ha) is usual although $3 \times 3(1,100$ plants/ha) may be used. Palm leaves placed to shade the newly-set seedlings help to avoid sun scald. 


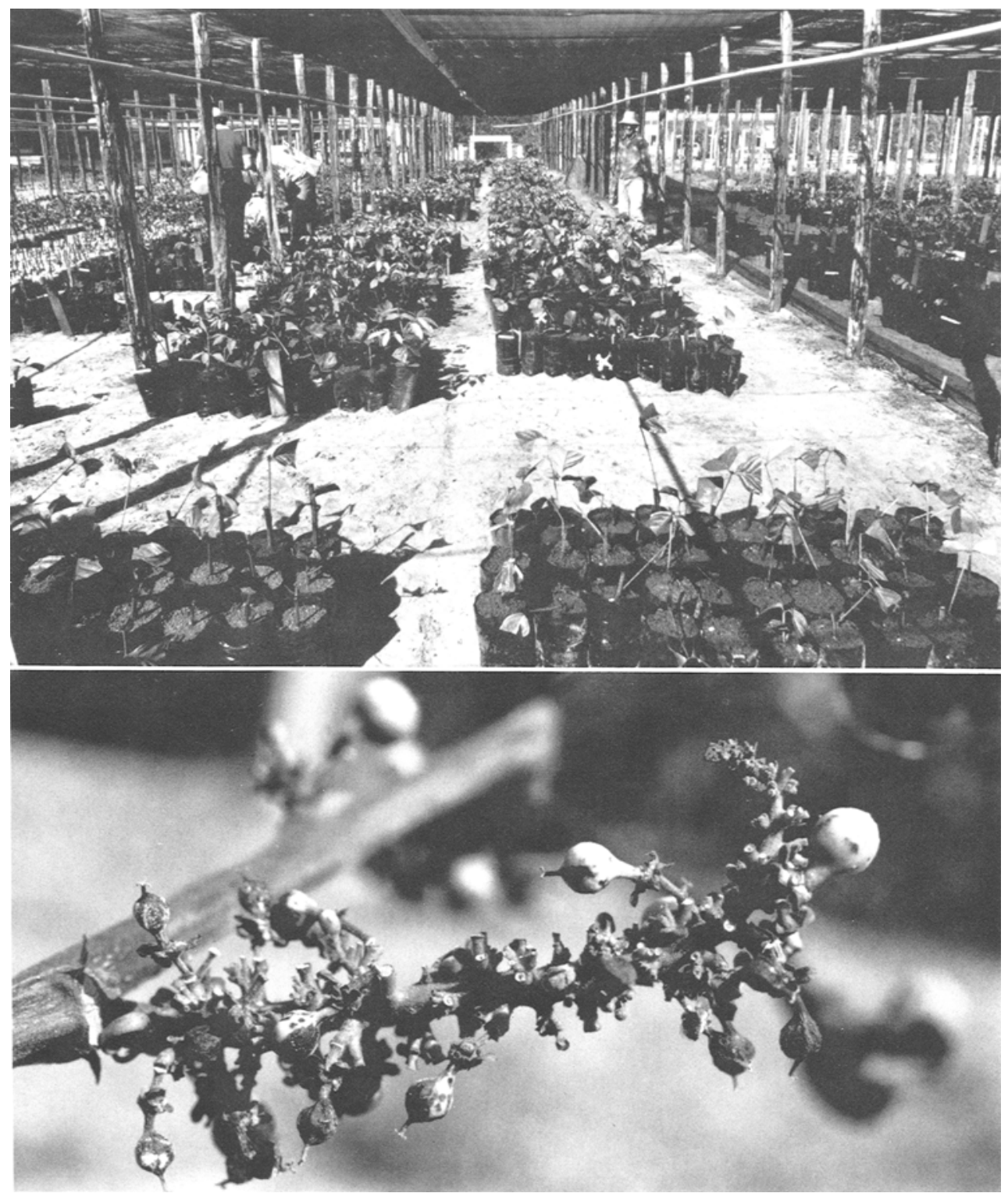

Fig. 9-10. Fig. 9 (above). Plastic 1-liter containers of rooted guaraná cuttings in a shaded nursery in Maués, Amazonas. Fig. 10 (below). Young fruiting cluster heavily attacked by anthracnose $\left(\times^{3 / 4}\right)$.

Except for occasional weeding little management effort is expended on the planting. A certain amount of size control pruning may be performed, and dead or broken branches removed, but plants are largely left to develop naturally. As mentioned earlier this "natural" growth is not the typical liana, in the absence of trees to serve as climbing supports. Ground covers are sometimes planted. Broadbean (Vicia faba L.) and kudzu (Pueraria lobata (Willd.) Ohwi) are examples. The 


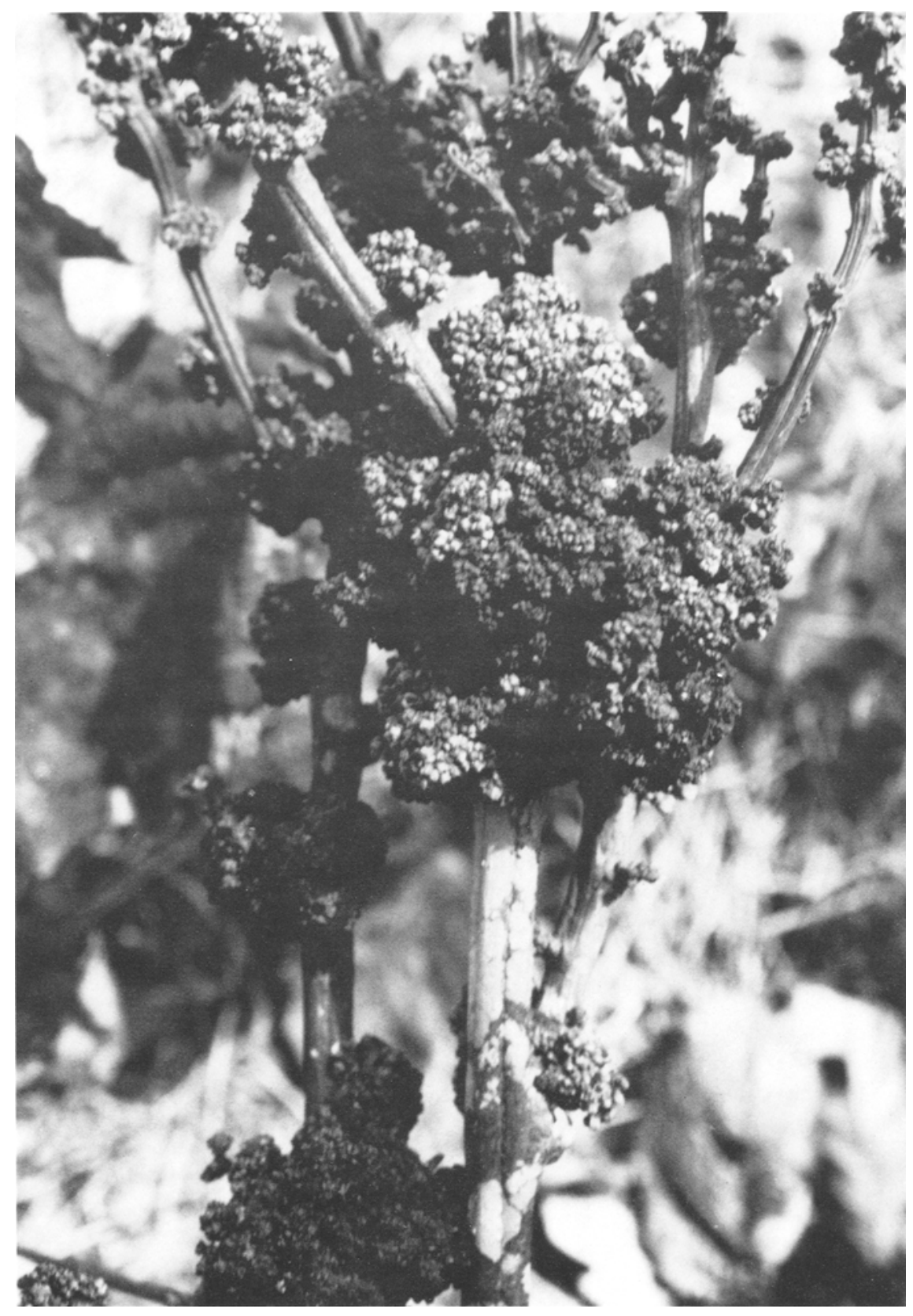

Fig. 11. Masses of proliferating tissue caused by Fusarium decemcellarare on a mature plant.

latter is so aggressive that constant care must be taken to prevent it from overgrowing the plantation.

Established plants bear literally hundreds of inflorescences. In certain respects plant growth resembles that of grapes. The long sprawling branches, which flower on new growth, are less viny than grapes but the similarity is nonetheless pro- 


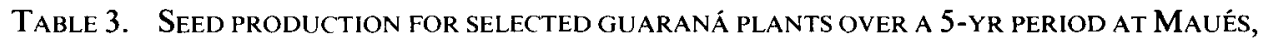
Amazonas, Brazil.a

\begin{tabular}{ccccccc}
\hline \hline $\begin{array}{c}\text { Plant } \\
\text { selection } \\
\text { no. }\end{array}$ & \multicolumn{7}{c}{ Production (kg) } \\
\hline 35 & 1976 & 1977 & 1978 & 1979 & 1980 & Av \\
\hline 35 & 9.1 & 2.3 & 2.6 & 5.7 & 2.5 & 4.4 \\
21 & 8.2 & 3.8 & 3.2 & 3.5 & 2.9 & 4.3 \\
05 & 6.8 & 1.3 & 2.8 & 1.8 & 1.3 & 2.8 \\
15 & 1.8 & 3.7 & 0.5 & 2.7 & 1.4 & 2.0 \\
13 & 4.7 & 2.5 & 0.8 & 0.5 & 1.4 & 2.0 \\
20 & 7.9 & 1.4 & 0.0 & 0.4 & 0.0 & 1.9 \\
01 & 2.5 & 0.3 & 1.5 & 0.7 & 0.9 & 1.2 \\
03 & 2.4 & 0.0 & 0.8 & 0.6 & 0.7 & 0.9 \\
18 & $\underline{2.0}$ & $\underline{0.3}$ & $\underline{0.5}$ & $\underline{0.0}$ & $\underline{1.0}$ & $\underline{0.8}$ \\
Average & 5.0 & $\underline{1.7}$ & 1.4 & 1.7 & 1.3 & 2.2 \\
\hline
\end{tabular}

"Corrêa and Escobar, 1981.

nounced. This suggests the possibility of training plants on trellises at much higher populations and employing pruning systems to maximize the amount of new growth. Indeed, considerable research has been done with wire supports, much of it using passion fruit (Passiflora sp.) as a temporary intercrop to furnish revenue for the first couple of years, until guaraná comes into heavy production. Both crops appear to thrive under similar growing conditions. Such intercropping has not yet been adopted to any degree in commercial plantations despite the generally encouraging research results.

Another species suggested as a companion crop with guaraná is peach palm (Guilielma gasipaes (H.B.K.) L. H. Bailey) (=Bactris gasipaes H.B.K.) locally known as pupunha. This useful palm begins bearing at an early age and continues for many years. Fruit are prized for food and it also serves as a source for heartsof-palm, another tropical delicacy. As plants produce basal sprouts, they regenerate when harvested for the latter product.

A common observation in guarana plantings is that they are intolerant of soil compaction. Plantations prepared by bulldozing trees and brush fail to grow as well as those cleared by felling and burning the trees, without the use of ground compacting machinery. The difference persists and cannot be accounted for by the fertilizer benefits of the ash. The severe effect of compaction on these redyellow oxisols is easily observed by the poor root penetration of annual crops on soils that have been subjected even slightly to mechanized equipment.

As is often true of plantation crops in the humid tropics, guaraná is besieged by troublesome diseases. The most severe is anthracnose caused by the fungus Colletotrychum guaranicola Alb., which attacks the foliage and inflorescence (Fig. 10). It is present in all plantations although severity varies from year to year. Differences in susceptibility occur among plants and this has encouraged an ambitious breeding program for resistance at federal research stations at Manaus and Maués. Individual plant production records have been kept for several years in selected plantations. Those plants that have consistently produced above-average yields and that show few disease symptoms have been chosen as parents. These well-directed breeding efforts have not been underway long enough to permit evaluation of their effectiveness. Also, elite parents are vegetatively propagated 
for establishment of superior clonal plantations. Mist propagation of softwood cuttings has been quite successful and its use can be expected to expand as more facilities become available. Clones differ greatly in rooting ability, however, ranging from total failure to 100\% success (Corrêa and Stolberg, 1981).

Another disease, caused by Fusarium decemcellarare Brick., produces a proliferation of buds resulting in large masses of nonproductive tissue (Fig. 11). This disease can be especially severe in nurseries where it contributes to seedling mortality (Batista and Bolkan, 1980). Heavily infected mature plants are unproductive and should be removed. A third fungal disease is red root rot caused by Ganoderma philippii (Bres. \& P. Henn.) Bres. The initial symptom of this soil-borne disease is yellowing of the foliage followed by the plants gradual decline and eventual death.

Guaraná is normally harvested from September to December or January. Ripe fruit is handpicked every other day. An average yield of $500 \mathrm{~g}$ of dried seed per plant is considered reasonably good. Potential yields are much greater as shown by the data from selected individual plants (Table 3 ). One is impressed with the dramatic differences in annual yield. Rainfall patterns and disease incidence likely account for the fluctuations. The most productive plants yield well above average even in off years.

Guaraná is gradually becoming available as a carbonated soft drink at the more cosmopolitan retail markets in the United States. While its therapeutic virtues are clouded in superstition and folklore, it remains a flavorful beverage with a vast unexploited world market. Eager to capitalize on expanded demand, the Brazilian government is encouraging increased production and vigorous research programs. Major advances in guaraná culture can be expected as this cherished plant of pre-Columbian Amazonia becomes known to the outside world.

\section{ACKNOWLEDGMENTS}

We appreciate the valuable administrative support provided by the Inter-American Institute for Cooperation on Agriculture through their Brasilia office; also, the research facilities, the technical assistance and critical comments of the Empresa Brasileira de Pesquisa Agropecuaria (EMBRAPA) administrators and staff in Manaus.

\section{LITERATURE CITED}

Batista, M. de Fátima, and H. A. Bolkan. 1980. O superbrotamento do guaranazeiro. Pesquisa em Andamento No. 3 UEPAE de Manaus.

Corrêa, M. P. F., and J. R. Escobar. 1981. Seleção fenotípica do guaranazeiro. Pesquisa em Andamento No. 29 UEPAE de Manaus.

, and A. G. Stolberg. 1981. Propagação vegetativa do guaranazeiro. Pesquisa em Andamento No. 23 UEPAE de Manaus.

Humbolt, A. von. 1822. Voyage aux régions équinoxiales du nouveau continent. VIII: 342. Paris.

Maravalhas, N. 1965. Estudos sobre guaraná e outras plantas produtoras de cafeína. Inst. Nacional de Pesquisas de Amazônia. (INPA-Química. Pub. 10).

Monteiro, M. Y. 1965. Antropogeografia do Guaraná. Cadernos da Amazônia 6. Inst. Nacional de Pesquisas de Amazônia.

Schultz, Q., and A. C. C. Valois. 1974. Estudos sobre o mecanismo de floração e frutificação do guaranazeiro. Inst. de Pesquisa Agropecuária do Amazonas Ocidental. Bol. Tecnico 4: 35-38.

Wallace, A. R. 1853. A Narrative of Travels on the Amazon and Rio Negro, with an Account of the Native Tribes, and Observations on the Climate, Geology, and Natural History of the Amazon Valley. Greenwood Press, New York. 